Tersedia Online di http://journal.unismuh.ac.id/index.php/otoritas

Otoritas : Jurnal Ilmu Pemerintahan, 6 (1), April 2016, 1-11

\title{
Pengaruh Pelaksanaan Prinsip-Prinsip Good Governance Terhadap Kinerja Pelayanan Publik Pada Badan Pertahanan Nasional (BPN) Kota Ambon
}

\author{
Aty Uar*) \\ Fakultas Ilmu Sosial, Program Studi Ilmu Administrasi Negara, Universitas Darussalam Ambon, \\ Jalan Waehakila Puncak Wara Ambon.
}

Diterima : 1 Februari 2016; Disetujui : 26 Maret 2016; Dipublikasikan 14 April 2016

\begin{abstract}
The purpose of this study to determine the effect of the implementation of the principles of good governance on the performance of public services at the National Land Agency (BPN) Ambon City. This research method is quantitative secera correlation with the intent to seek the influence of the independent variable $(X)$ to the dependent variable $(Y)$. The research instrument used consisted of questionnaires, observations, review of documents. Analysis showed that the implementation of the principles of good governance which has a high correlation of 0.77 and significant at the $95 \%$ confidence level (0.05) with the performance of public services at BPN Ambon City. This means that the hypothesis was formulated that there is a significant relationship between the implementation of the principles of good governance with the performance of public services in the city of Ambon BPN verified.
\end{abstract}

Keywords: good governance; performance; public services

\begin{abstract}
Abstrak
Tujuan penelitian ini untuk mengetahui pengaruh pelaksanaan prinsip-prinsip good governance terhadap kinerja pelayanan publik pada Badan Pertanahan Nasional (BPN) Kota Ambon. Metode penelitian ini yaitu kuantitatif secera korelasional dengan maksud untuk mencari pengaruh antara variabel independent $(X)$ dengan variabel dependent $(Y)$. Instrumen penelitian yang digunakan terdiri dari quesioner, observasi, telaah dokumen. Analisa menunjukkan bahwa pelaksanaan prinsip-prinsip good governance mempunyai hubungan yang tinggi yakni sebesar 0,77 dan signifikan pada taraf kepercayaan $95 \%(0,05)$ dengan kinerja pelayanan publik pada BPN Kota Ambon. Ini berarti bahwa hipotesis yang dirumuskan yakni ada hubungan yang signifikan antara pelaksanaan prinsip-prinsip good governance dengan kinerja pelayanan publik pada BPN Kota Ambon teruji kebenarannya.
\end{abstract}

Kata kunci : good governance; kinerja; pelayanan publik

Cara Penulisan Sitasi : Uar, A. (2016). Pengaruh Pelaksanaan Prinsip-Prinsip Good Governance Terhadap Kinerja Pelayanan Publik Pada Badan Pertahanan Nasional (BPN) Kota Ambon. Otoritas : Jurnal Ilmu Pemerintahan, 6 (1), 1-11.

${ }^{*}$ Penulis Korespondensi.

E-Mail : atyuar@yahoo.co.id

Copyright (C) 2016, Otoritas : Jurnal Ilmu Pemerintahan, p-ISSN: 2088-3706, e-ISSN: 2502-9320 
Tersedia Online di http://journal.unismuh.ac.id/index.php/otoritas

Otoritas : Jurnal Ilmu Pemerintahan, 6 (1), April 2016, 2

\section{Pendahuluan}

Good governance merupakan prasyarat utama untuk mewujudkan aspirasi masyarakat dalam mencapai tujuan dan cita-cita bangsa dan Negara. Dalam rangka hal tersebut, diperlukan pengembangan dan penerapan sistem pertanggungjawaban yang tepat, jelas dan nyata sehingga dalam penyelenggaraan pemerintahan dapat berlangsung secara berdaya guna, berhasil guna bertanggung jawab serta bebas KKN. Konsep good governance untuk dilaksanakan dalam penyelenggaraan kehidupan berbangsa dan bernegara dilatar belakangi oleh banyak faktor. Namun demikian salah satu faktor yang terbesar adalah ketidak berdayaan pemerintah negara-negara berkembang dalam menghadapi era globalisasi yang penuh dengan persaingan kompetensi standar tinggi. Pemerintah tidak lagi menjadi pemain tetapi mengharapkan peran lebih besar dari sektor swasta dan masyarakat sipil.

Sedarmayanti (2012) menjelaskan good governance adalah merupakan proses penyelenggaraan kekuasaan negara dalam melaksanakan penyediaan publik goods and service disebut governance (pemerintah atau kepemerintahan), sedangkan praktik terbaiknya disebut good governance (kepemerintahan yang baik). Sejalan dengan hal tersebut governance sering diartikan sebagai kepemerintahan yang baik. World Bank mendefinisikan good governance sebagai suatu penyelenggaraan manajemen pembangunan yang solid dan bertanggung jawab dan sejalan dengan prinsip demokrasi dan pasar yang efisien, penghindaran salah alokasi dana investasi, dan pencegahan korupsi baik secara politik maupun administratif menjalankan disiplin anggaran serta penciptaan legal and political framework bagi tumbuhnya aktivitas usaha (Mardiasmo, 2009).

Peran pemerintah yang cukup besar ini berimplikasi pada bagaimana birokrasi mampu melaksanakan tugas dan fungsinya masing-masing. Oleh karena itu pemerintah harus terlibat langsung dalam penyediaan barang dan jasa yang diperlukan oleh masyarakat, serta secara aktif terlibat di dalam kehidupan sosial masyarakat. Berkenaan dengan upaya pelayanan dan mewujudkan kesejahteraan rakyatnya, birokrasi publik memberikan andil yang relatif besar (Sulistiyani, 2011).

Jelaslah bahwa perubahan paradigma organisasi yang memerlukan pendekatan baru di dalam pengelolaannya adalah pendayagunaan sumber daya manusia untuk mencapai tujuan organisasi yang diharapkan. Dengan demikian dapat dikatakan bahwa kinerja organisasi tidak lepas dari kinerja pelayanan pegawai sebagai salah satu unsur organisasi, memegang peranan penting dalam usaha mencapai tujuan organisasi. Oleh karena itu tanpa manusia dalam suatu organisasi maka tujuan organisasi yang telah ditentukan tidak akan tercapai sebagaimana yang diharapkan. Selanjutnya manusia merupakan salah satu unsur organisasi yang paling dinamis, artinya menginginkan perubahan, dengan demikian kedudukan manusia dalam organisasi tidak dapat disamakan dengan unsur-unsur lain. Sehingga dalam organisasi pengelolaan manusia sebagai sumber daya organisasi agar memiliki kemampuan untuk mewujudkan good governance.

Good governance adalah cita-cita yang menjadi misi setiap penyelenggaraan suatu negara, termasuk Indonesia. good governance dapat diartikan sebagai prinsip dalam mengatur pemerintahan yang memungkinkan layanan publiknya efisien, sistem pengadilannya bisa diandalkan dan administrasinya bertanggung jawab pada publik. (Santoso, 2008).

Kondisi penerapan good governance ini peneliti telusuri pada Badan Pertanahan Nasional (BPN) Kota Ambon yang merupakan salah satu mitra pemerintah, oleh karena itu sebagai mitra pemerintah Kota Ambon dalam penye- 
Tersedia Online di http://journal.unismuh.ac.id/index.php/otoritas

Otoritas : Jurnal Ilmu Pemerintahan, 6 (1), April 2016, 3

lenggaraan pemerintah Kota serta merupakan unsur pelaksanaan asas desesntralisasi. Maka dalam rangka penciptaan good governance, Badan Pertanahan Nasional (BPN) Kota Ambon sangat berperan penting, dengan kata lain Badan Pertanahan Nasional (BPN) Kota Ambon harus menjadi suatu organisasi yang mempunyai kinerja yang baik agar dapat mencapai sasaran yang diinginkan. Mengingat bahwa kinerja pelayanan publik dari suatu organisasi itu adalah untuk mencapai tujuan tertentu yang sudah ditetapkan sebelumnya, maka informasi tentang kinerja pelayanan publik merupakan suatu hal yang sangat penting.

Informasi tentang kinerja pelayanan publik dapat digunakan suntuk mengevaluasi apakah proses kerja yang dilakukan organisasi selama ini sudah berjalan dengan tujuan yang diharapkan atau belum. Akan tetapi dalam kenyataannya banyak organisasi yang justru kurang atau bahkan tidak jarang ada yang tidak mempunyai informasi tentang kinerja pegawainya. Untuk menilai kinerja pelayanan publik suatu organisasi ini tentu saja diperlukan indikator-indikator atau kriteria-kriteria untuk mengukurnya secara jelas. tanpa indikator dan kriteria yang jelas tidak akan ada arah yang dapat digunakan untuk menentukan mana yang relatif lebih efektif diantara alternatif alokasi sumber daya yang berbeda, alternatif desain-desain organisasi yang berbeda dan diantara pilihan-pilihan pendistribusian tugas dan wewenang yang berbeda. Sekarang permasalahanya adalah kinerja apa yang digunakan untuk menilai seorang organisasi.

Adapun prinsip-prinsip good governance dikemukakan oleh Santoso (2008), terdiri dari: (1) Partipasitory, setiap pembuatan peraturan dan atau kebijakan selalu melibatkan unsur masyarakat (melalui wakil-wakilnya). (2) Rule of law, harus ada perangkat hukum yang menindak para pelanggar, menjamin perlindungan ham, tidak memihak, berlaku pa- da semua warga. (3) Transparency, adanya ruang kebebasan untuk memperoleh informasi publik bagi warga yang membutuhkan (diatur oleh undang-undang). Ada ketegasan antara rahasia negara dengan informasi negara yang terbuka untuk publik. (4) Responsiveness, lembaga publik harus mampu merespon kebutuhan masyarakat, terutama yang berkaitan dengan "basicneed" (kebutuhan dasar) dan HAM (hak sipil, hak politik, hak ekonomi, hak sosial, dan hak budaya). (5) Consensus, jika ada perbedaan kepentingan yang mendasar di dalam masyarakat, penyelesaian harus mengutamakan cara dialog atau musyawarah menjadi consensus. (6) Persamaan hak, pemerintahan harus menjamin bahwa semua pihak, tanpa terkecuali, dilibatkan di dalam proses politik, tanpa ada satu pihak pun yang dikesampingkan. (7). Efektifitas dan efisiensi, pemerintah harus efektif dan efisien dalam memproduksi output berupa aturan, kebijakan, pengelolaan keuangan negara, dll. (8) Akuntabilitas, suatu perwujudan kewajiban dari suatu instansi pemerintahan untuk mempertanggung jawabkan keberhasilan dan kegagalan pelaksanaan misinya.

Selanjutnya prinsip-prinsip good governance terdapat empat unsur atau prinsip utama yang dapat memberi gambaran yang berciri kepemerintahan yang baik, sebagaimana yang dikemukakan Sedarmayanti (2012) yaitu pertama adalah akuntabilitas, adanya kewajiban bagi aparatur pemerintah untuk bertindak selaku penanggung jawab dan penanggung gugat atas segala tindakan dan kebijakan yang di tetapkannya. Kedua adalah transparansi, kepemerintahan yang baik akan bersifat transparansi terhadap rakyatnya, baik ditingkat pusat maupun daerah. Ketiga adalah keterbukaan, menghendaki terbukanya kesempatan bagi rakyat untuk mengajukan tanggapan dan kritik terhadap pemerintahan yang dinilainya tidak transparan. Terakhir adalah aturan 
Tersedia Online di http://journal.unismuh.ac.id/index.php/otoritas

Otoritas : Jurnal Ilmu Pemerintahan, 6 (1), April 2016, 4

hukum, kepemerintahan yang baik mempunyai karakteristik berupa jaminan kepastian hukum dan rasa keadilan masyarakat terhadap setiap kebijakan publik yang ditempuh.

Hal ini memiliki korelasi dari penelitian terdahulu seperti Tomuka (2013) melihat Penerapan Prinsip-Prinsip Good Governance Dalam Pelayanan Publik ditemukan bahwa faktor-faktor yang mendorong terselenggaranya prinsipprinsip good governance dalam pelayanan publik adalah prinsip partisipasi, ketentuan dan aturan-aturan yang berlaku, prinsip transparansi, dan prinsip responsive. Secara umum pelayanan publik yang mengedepankan prinsip-prinsip good governance.

Penerapan prinsip-prinsip good governance dalam meningkatkan kinerja organisasi pelayanan publik diteliti Nubatonis (2014) menunjukkan dari ketujuh prinsip good governance dapat diimplementasikan dengan baik yakni prinsip profesionalitas, akuntabilitas, transparansi, pelayanan prima, demokrasi dan partisipasi, efesiensi dan efektivitas, serta supermasi hukum. Faktor-faktor yang mempengaruhi implementasi prinsipprinsip good governance antara lain kurangnya sumber daya manusia, kurangnya sarana dan prasarana, kurangnya kesadaran masyarakat akan pentingnya dokumen-dokumen kependudukan, masyarakat kota malang sebagian besar berada di luar kota, kurangnya kesabaran masyarakat terhadap proses pelayanan, letak instansi cukup jauh. dampak dari implementasi prinsipprinsip good governance yaitu kinerja organisasi semakin meningkat serta hak dan kewajiban masyarakat dapat terpenuhi.

Hasil penelitian Siringoringo (2015), memberikan bukti bahwa pelaksanaan good governance tidak mempengaruhi peningkatan kepatuhan wajib pajak orang pribadi di kota Bekasi, sehingga sepertinya pelaksanaan good governance men- jadi sia-sia, oleh karena itu sangat penting bagi Direktorat Jendral Pajak untuk melakukan sosialisasi yang menyeluruh kepada wajib pajak orang pribadi di kota bekasi, bahwa sekarang ini DJP telah menjalankan good governance dalam menjalankan fungsinya, serta harus diterapkan secara maksimal dan berkelanjutan.

Sejumlah penelitian yang dikemukakan sebelumnya menunjukkan perbedaan dari segi penerapan good governance dengan fokus pelayanan maupun kinerja. Selanjutnya ukuran pokok atau prinsip good governance dalam penelitian ini adalah akuntabilitas, transparansi, responsivitas atau ketanggapan dikaitkan dengan pengaruhnya terhadap sejumlah indikator kinerja pelayanan publik di Kota Ambon. Secara spesifik penelitian ini dilakukan pada Badan Pertanahan Nasional (BPN) Kota Ambon yang memberikan pelayanan umum dalam bidang kesejateraan sosial sudah seharusnya memberikan pelayanan yang terbaik. Untuk mendapatkan pelayanan yang demikian, pegawai Badan Pertanahan Nasional (BPN) Kota Ambon harus memiliki motivasi untuk mengerjakan pekerjaannya agar kinerja pelayanan publik organisasi dapat tercapai. Namun kenyataannya selama ini pada Badan Pertanahan Nasional (BPN) Kota Ambon terdapat fenomenafenomena/gejala yang mempengaruhi pelaksanaan prinsip-prinsip good governance antara lain (1) banyak pegawai yang datang terlambat dan menunda pekerjaannya. Hal ini tentu berdampak pada pemberian pelayanan yang tidak memuaskan. Misalnya pelayanan jasa bagi masyarakat yang seharusnya 1 sampai 2 hari saja namun tertunda hingga berminggu-minggu bahkan berbulanbulan. (2) kapabilitas kebijakan yang rendah dan manajemen keuangan yang lemah. Misalnya masyarakat yang sering mengurus Sertifikat selalu terlambat dalam penanganannya. (3) peraturan yang terlalu berbelit-belit dan sewenangwenang, misalnya urusan pembuatan ser- 
Tersedia Online di http://journal.unismuh.ac.id/index.php/otoritas

Otoritas : Jurnal Ilmu Pemerintahan, 6 (1), April 2016, 5

tifikat bagi masyarakat yang berhak menerimanya selalu dililit dengan aturan yang berbelit-belit.

Bertolak dari latar belakang dan uraian permasalahan tersebut diatas, maka tujuan penelitian ini untuk mengetahui pengaruh pelaksanaan prinsip-prinsip good governance terhadap kinerja pelayanan publik pada Badan Pertanahan Nasional (BPN) Kota Ambon. Hal ini dapat dijadikan hipotesis dalam penelitian ini yang menarik untuk diuji kebenarannya.

\section{Metode Penelitian}

Tipe penelitian ini adalah penelitian korelasional dengan analisa kuantitatif dengan maksud untuk mencari pengaruh antara variabel independent (X) dengan variabel dependent (Y). Dengan metode ini diharapkan dapat menjelaskan fenomena yang ada berdasarkan data dan informasi yang diperoleh. Penelitian ini akan dilaksanakan pada Badan Pertanahan Nasional (BPN) Kota Ambon, Populasi dalam penelitian ini adalah pegawai Bagian Pelayanan dan Pengurusan Sertifikat yang ada pada yang berjumlah 35 orang. Badan Pertanahan Nasional (BPN) Kota Ambon. Instrumen penelitian yang digunakan terdiri dari quesioner, observasi, telaah dokumen.

Data yang berhasil dikumpulkan kemudian dianalisis baik secara kuantitatif maupun kualitatif. Analisis secara kuantitatif menggunakan rumus statistik Korelasi Produk Moment untuk mengetahui pengaruh dari variabel-variabel yang teliti, maka digunakan rumus sebagai berikut (Faisal, 2010) :

$$
r x y=\frac{N\left(\sum X Y\right)-\left(\sum X\right)\left(\sum Y\right)}{\sqrt{\left[N\left(\sum X^{2}\right)\left(\sum X\right)^{2}\right]\left[N\left(\sum Y^{2}\right)\left(\sum Y\right)^{2}\right]}}
$$

Dimana :

rxy $=$ Koefisien korelasi $\mathrm{r}$

$\mathrm{X}=$ Skor dalam distribusi variabel $\mathrm{X}$

$\mathrm{Y}=$ Skor dalam distribusi variabel

$\mathrm{YN}=$ Banyaknya sampel yang diteliti
Untuk mengetahui signifikansi hubungan antara kedua variabel digunakan rumus t-test yang dikemukakan oleh Sugiyono (2003) pada taraf signifikansi $95 \%(0,05)$ sebagai berikut :

$$
t=\frac{r \sqrt{n-2}}{\sqrt{t-r^{2}}}
$$

Bersumber dari uraian yang dikemukakan sebelumnya maka dapat dirumuskan hipotesis bahwa ada pengaruh yang signifikan antara pelaksanaan prinsip-prinsip good governance dengan kinerja pelayanan publik pada Badan Pertanahan Nasional (BPN) Kota Ambon. Hipotesis tersebut di atas mengandung 2 variabel pokok yaitu pelaksanaan prinsip-prinsip good governance sebagai variabel $(X)$ dan kinerja pelayanan publik sebagai variabel (Y).

\section{Hasil dan Pembahasan}

Berdasarkan Hasil dari daftar kuesioner dan jawaban dalam tabel frekuensi menyangkut Transparansi Badan Pertanahan (BPN) Kota Ambon dalam Penyelesaian Sertifikat Hak Milik Atas Tanah terungkap bahwa dalam penyelesaian sertifikat hak milik atas tanah oleh Badan Pertanahan (BPN) kota Ambon sebagian Responden mengatakan pihak BPN kadang kurang memberikan penjelasan menyangkut aturan dan persyaratan pengurusan tanah , Kurang adanya pelayanan yang tepat dalam penyelesaian dan kepengurusan sertifikat hak milik atas tanah oleh Badan Pertanahan (BPN) Kota Ambon, ini merupakan satu kelemahan besar yang dibuat, apalagi menyangkut status kepemilikan tanah yang akan disertifikasi.

Terlihat bahwa baik dari pihak BPN maupun masyarakat kurang menyadari akan adanya tanggung jawab dan kewajiban masing-masing, BPN selaku Pelayan bagi masyarakat tidak atau kurang memiliki SDM yang mempunyai kemampuan dalam pembuatan sertifikat 
Tersedia Online di http://journal.unismuh.ac.id/index.php/otoritas

Otoritas : Jurnal Ilmu Pemerintahan, 6 (1), April 2016, 6

tanah, Keterlambatan waktu oleh pihak BPN dalam proses penyelesaian Sertifikat tanah yang diusulkan masyarakat, Tidak transparan dan tanggap terhadap penyampaian informasi kepada masyarakat sertifikat tanah, sementara dari masyarakat sendiri banyaknya memiliki tanah yang bermasalah, tidak ada kesadaran untuk mengurus sertifikat hak milik atas tanah. Hal ini akan menjadi tantangan berat bagi BPN Kota Ambon untuk menatanya kembali.

\subsection{Pengaruh pelaksanaan prinsip- prinsip good governance}

Berdasarkan Hasil dari daftar kuesioner dan jawaban dalam tabel frekuensi menyangkut Transparansi Badan Pertanahan (BPN) Kota Ambon dalam Penyelesaian Sertifikat Hak Milik Atas Tanah terungkap bahwa dalam penyelesaian sertifikat hak milik atas tanah oleh Badan Pertanahan (BPN) kota Ambon sebagian Responden mengatakan pihak BPN kadang kurang memberikan penjelasan menyangkut aturan dan persyaratan pengurusan tanah, Kurang adanya pelayanan yang tepat dalam penyelesaian dan kepengurusan sertifikat hak milik atas tanah oleh Badan Pertanahan (BPN) Kota Ambon, ini merupakan satu kelemahan besar yang dibuat, apalagi menyangkut status kepemilikan tanah yang akan disertifikasi. Terlihat bahwa baik dari pihak BPN maupun masyarakat kurang menyadari akan adanya tanggung jawab dan kewajiban masing-masing, BPN selaku Pelayan bagi masyarakat tidak atau kurang memiliki SDM yang mempunyai kemampuan dalam pembuatan sertifikat tanah, Keterlambatan waktu oleh pihak BPN dalam proses penyelesaian Sertifikat tanah yang diusulkan masyarakat, Tidak transparan dan tanggap terhadap penyampaian informasi kepada masyarakat sertifikat tanah, sementara dari masyarakat sendiri banyaknya memiliki tanah yang bermasalah, tidak ada kesadaran untuk mengurus ser- tifikat hak milik atas tanah. Hal ini akan menjadi tantangan berat bagi BPN Kota Ambon untuk menatanya kembali.

\subsection{Identitas responden}

\section{a. Jenis Kelamin}

Tabel 1. Frekuensi Jenis Kelamin Responden (Hasil Penelitian, 2014)

\begin{tabular}{cccc}
\hline No & Jenis Ke- & Frekuensi & Persentase \\
\hline 1 & Laki - Laki & 15 & 43 \\
\hline 2 & Perempuan & 20 & 57 \\
\hline & Jumlah & 35 & 100 \\
\hline
\end{tabular}

Berdasarkan data tabel 1 dapat dilihat bahwa pegawai laki-laki berjumlah 15 orang atau 43 persen dan pegawai perempuan jumlahnya 20 orang atau 57 persen Dengan demikian dapat disimpulkan bahwa pegawai di BPN Kota Ambon lebih banyak pegawai perempuan dari pegawai laki-laki.

\subsection{Kepangkatan responden}

Tabel 2. Frekuentasi Golongan Kepangkatan Responden (Hasil Penelitian, 2014)

\begin{tabular}{cccc}
\hline No & $\begin{array}{c}\text { Golongan } \\
\text { Kepangkatan }\end{array}$ & Frekuensi & $\begin{array}{c}\text { Persen- } \\
\text { tase }\end{array}$ \\
\hline 1 & GOL I & - & - \\
\hline 2 & GOL II & 2 & 6 \\
\hline 3 & GOL III & 28 & 80 \\
\hline 4 & GOL IV & 5 & 14 \\
\hline & T O T A L & 35 & 100 \\
\hline
\end{tabular}

Tabel 2 menggambarkan bahwa responden yang bergolongan kepangkatan Gol. II sebanyak 2 orang atau tujuh persen, Gol. III sebanyak 28 orang atau 80 persen, dan Gol. IV sebanyak 5 orang atau 14 persen.

\subsection{Masa kerja responden}

Tabel 3 secara jelas dan rinci telah menggambarkan bahwa responden yang masa kerja antara 1 - 5 tahun sebanyak 1 orang atau tiga persen, 6-10 tahun sebanyak 2 orang atau enam persen, 11- 
Tersedia Online di http://journal.unismuh.ac.id/index.php/otoritas

Otoritas : Jurnal Ilmu Pemerintahan, 6 (1), April 2016, 7

15 tahun sebanyak 5 orang atau empat belas persen, 16-20 tahun sebanyak 14 orang atau empat puluh persen, dan 21 tahun keatas sebanyak 13 orang atau 37 persen.

Tabel 3. Frekuensi Masa Kerja Responden (Hasil Penelitian, 2014)

\begin{tabular}{cccc}
\hline No & Masa Kerja & Frekuensi & Persentase \\
\hline 1 & $1-5$ Tahun & 1 & 3 \\
\hline 2 & $6-10$ Tahun & 2 & 6 \\
\hline 3 & $11-15$ Tahun & 5 & 14 \\
\hline 4 & $16-20$ Tahun & 14 & 40 \\
\hline 5 & $\begin{array}{l}\text { 21 Tahun } \\
\text { Ke atas }\end{array}$ & 13 & 37 \\
\hline & TOTAL & 35 & 100 \\
\hline
\end{tabular}

\subsection{Tingkat pendidikan responden}

Tabel 4. Frekuensi Tingkat Pendidikan Responden (Hasil Penelitian, 2014)

\begin{tabular}{clcc}
\hline No & $\begin{array}{c}\text { Tingkat } \\
\text { Pendidikan }\end{array}$ & Frekuensi & Persentase \\
\hline 1 & SD/Sederajat & - & - \\
\hline 2 & SMP/Sederajat & - & - \\
\hline 3 & SMA/Sederajat & 12 & 34 \\
\hline 4 & $\begin{array}{l}\text { Pendidikan } \\
\text { Tinggi }\end{array}$ & 23 & 66 \\
\hline & T O T A L & 35 & 100 \\
\hline
\end{tabular}

Tabel 4 menggambarkan secara jelas bahwasanya responden yang berpendidikan SD/Sederajat tidak ada, SMP/sederajat tidak ada, SMA/sederajat sebanyak 15 orang atau lima puluh delapan persen, dan Perguruan tinggi sebanyak 11 orang atau 42 persen.

\subsection{Umur responden}

Tabel 5 menggambarkan secara jelas bahwasanya jumlah responden yang berada pada tingkatan, umur $24-29$ tahun sebanyak 1 orang atau tiga persen, umur 30 - 35 tahun sebanyak 1 orang atau tiga persen, umur 36 - 40 tahun sebanyak 4 orang atau sebelas persen, umur 41 - 45 tahun sebanyak 10 orang atau dua puluh sembilan persen, umur 46 - 50 tahun sebanyak 6 orang atau tujuh belas persen, dan umur 51 tahun ke atas sebanyak 13 orang atau tiga puluh tujuh persen.

Tabel 5. Frekuensi Umur Responden (Hasil Penelitian, 2014)

\begin{tabular}{cccc}
\hline No & $\begin{array}{c}\text { Umur } \\
\text { Responden }\end{array}$ & Frekuensi & Persentase \\
\hline 1 & $18-23$ Tahun & - & - \\
\hline 2 & $24-29$ Tahun & 1 & 3 \\
\hline 3 & $30-35$ Tahun & 1 & 3 \\
\hline 4 & $36-40$ Tahun & 4 & 11 \\
\hline 5 & $41-45$ Tahun & 10 & 29 \\
\hline 6 & $46-50$ Tahun & 6 & 17 \\
\hline 7 & 51 tahun keatas & 13 & 37 \\
\hline & TOTAL & 35 & 100
\end{tabular}

\subsection{Deskripsi data hasil penelitian}

Pada bagian ini akan dikemukakan analisis dan interprestasi data dalam kaitannya dengan penelitian yang dilakukan. Data-data yang berhasil dikumpulkan dengan menggunakan instrumen penelitian seperti yang telah disebutkan, kemudian akan dianalisis dengan menggunakan analisis Statistik Korelasi Produk Momen.

Sebelum analisis data dilakukan, terlebih dahulu akan dikemukakan pedoman analisis sebagai berikut :

1. Mengidentifikasikan secara operasional konsep yang akan diukur.

2. Melakukan uji coba skala pengukur tersebut pada jumlah responden.

3. Mempersiapkan tabel tabulasi.

4. Setiap jawaban responden diberi nilai sebagai berikut :
a. Jawaban " a" diberi nilai " 3 ".
b. Jawaban " b" diberi nilai " 2 "
c. Jawaban " $c$ " diberi nilai " 1 "

5. Menghitung korelasi antara masingmasing pernyataan dengan skala total. 
Tersedia Online di http://journal.unismuh.ac.id/index.php/otoritas

Otoritas : Jurnal Ilmu Pemerintahan, 6 (1), April 2016, 8

Kemudian untuk mengetahui tinggi rendahnya hubungan yang terjadi antara dua variabel pokok yang ada dalam penelitian ini digunakan pembobotan sebagai berikut :

$0,00-0,19=$ Korelasi yang rendah sekali

$0,20-0,39=$ Korelasi yang rendah tetapi ada

$0,40-0,69=$ Korelasi yang sedang

$0,70-0,79=$ Korelasi yang tiggi

$0,80-1,00=$ Korelasi yang tinggi sekali.

Berdasarkan pedoman tersebut diatas, data-data yang menyangkut variabel bebas dan variabel terikat akan di analisis dalam sub bab analisis data.

\subsection{Analisis data}

\subsubsection{Variabel bebas (pelaksanaan prinsip- prinsipgoodgovernance)}

Variabel ini akan diukur dengan menggunakan indikator-indikator yaitu transparansi, responsivitas, akuntabilitas.

Untuk mengetahui tanggapan responden atas indikator-indikator tersebut di atas diajukan sejumlah pertanyaan. Tanggapan responden tentang pertanyaan-pertanyaan yang diajukan, seperti tertera pada tabel 6 .

Tabel 6 memperlihatkan tanggapan responden sebagai berikut yaitu sebanyak 12 orang responden atau 34 persen mengatakan pegawai dalam proses penyelesaian sertifikat selalu transparan, 17 orang responden atau empat puluh Sembilan persen mengatakan kadangkadang dan 6 orang responden atau tujuh belas persen mengatakan tidak pernah dilakukan.

Selanjutnya Sejumlah 14 orang responden empat puluh persen, mengatakan pegawai dalam menyelesaikan permohonan pembuatan sertifikat selalu ada proses akuntabilitas punya respon positif terhadap permohonan pembuatan sertifikat, 16 orang responden empat puluh persen, mengatakan kadangkadang dan 5 orang responden atau empat belas persen mengatakan tidak pernah.
Sebanyak 14 orang responden atau empat puluh persen, mengatakan pegawai dalam menyelesaikan pembuatan dan permohonan sertifikat dari masyarakat selalau ada proses akuntabilitas yang baik, 16 orang responden atau empat puluh enam persen mengatakan kadangkadang, dan 5 orang responden atau empat belas persen, mengatakan tidak pernah.

\subsubsection{Variabel terikat (kinerja pela- yanan publik)}

Variabel ini akan diukur dengan menggunakan indikator-indikator yaitu, produktivitas kerja, kualitas layanan, kepercayaan masyarakat.

Tanggapan responden tentang pertanyaan-pertanyaan yang diajukan dalam hubungannya dengan variabel terikat seperti tertera pada tabel 7 .

Dalam tabel 7 memperlihatkan tanggapan responden yaitu, sejumlah 15 orang responden atau empat puluh tiga persen mengatakan bahwa produktivitas kerja pegawai selalu didasarkan pada prinsip efisiensi, 16 orang atau empat puluh enam persen mengatakan kadangkadang dan 4 orang atau sebelas persen mengatakan tidak pernah.

Selanjutnya sebanyak 15 orang atau empat puluh tiga persen mengatakan bahwa kepuasan masyarakat terhadap kualitas layanan terhadap permohonan pembuatan sertifikat tinggi, 14 orang atau empat puluh persen mengatakan sedang, dan 6 orang atau tujuh belas persen mengatakan kepuasan masyarakat terhadap kualitas layanan rendah.

Sejumlah 13 orang responden atau tiga puluh tujuh persen mengatakan kepercayaan masyarakat terhadap pelaksanaan penyelesaian sertifikat tinggi, 16 orang responden atau empat puluh enam persen mengatakan kurang tepat dan 6 orang responden tujuh belas persen mengatakan Kepercayaan masyarakat terhadap pelaksanaan penyelesaian sertifikat rendah. 
Tersedia Online di http://journal.unismuh.ac.id/index.php/otoritas

Otoritas : Jurnal Ilmu Pemerintahan, 6 (1), April 2016, 9

Tabel 6. Tanggapan Responden Tentang Variabel Bebas (Pelaksanaan Prinsip-Prinsip Good Governance) (Hasil Penelitian, 2014)

\begin{tabular}{|c|c|c|c|c|}
\hline No. & Bentuk Pertanyaan dan Distribusi Jawaban & $\mathrm{f}$ & $\%$ & Ket \\
\hline \multirow[t]{4}{*}{1} & $\begin{array}{l}\text { Dalam proses penyelesaian permohonanan pembuatan sertifikat tanah } \\
\text { apakah ada Transparansi dari Pegawai? }\end{array}$ & & & \multirow{12}{*}{$\mathrm{N}=35$} \\
\hline & a. Selalu & 12 & 34 & \\
\hline & b. Kadang-kadang & 17 & 49 & \\
\hline & c. Tidak pernah & 16 & 17 & \\
\hline \multirow[t]{4}{*}{2} & $\begin{array}{l}\text { Ada Respons positif dari petugas terhadap permohonan Pembuatan/ } \\
\text { penyelesaian Sertifikat? }\end{array}$ & & & \\
\hline & a. Selalu & 14 & 40 & \\
\hline & b. Kadang-kadang & 16 & 46 & \\
\hline & c. Tidak pernah & 5 & 14 & \\
\hline \multirow[t]{4}{*}{3} & $\begin{array}{l}\text { Apakah ada Proses Akuntabilitas terhadap penyelesaian dan pengurusan } \\
\text { Sertifikat sampai selesai? }\end{array}$ & & & \\
\hline & a. Selalu & 14 & 40 & \\
\hline & b. Kadang-kadang & 16 & 46 & \\
\hline & c. Tidak pernah & 5 & 14 & \\
\hline
\end{tabular}

Tabel 7. Tanggapan Responden Tentang Variabel Terikat (Kinerja Pelayanan Publik) (Hasil Penelitian, 2014)

\begin{tabular}{|c|c|c|c|c|}
\hline No. & Bentuk Pertanyaan dan Distribusi Jawaban & $\mathrm{f}$ & $\%$ & Ket \\
\hline 1 & $\begin{array}{l}\text { Produktivitas kerja pegawai selalu didasarkan pada prinsip efisiensi } \\
\text { a. Selalu } \\
\text { b. Kadang -Kadang } \\
\text { c. Tidak Pernah }\end{array}$ & $\begin{array}{c}15 \\
16 \\
4\end{array}$ & $\begin{array}{l}43 \\
46 \\
11\end{array}$ & \\
\hline 2 & $\begin{array}{l}\text { Apakah ada Kepuasan masyarakat terhadap kualitas layanan Sertifikat? } \\
\text { a. Tinggi } \\
\text { b. Sedang } \\
\text { c. Rendah }\end{array}$ & $\begin{array}{c}15 \\
14 \\
6\end{array}$ & $\begin{array}{l}43 \\
40 \\
17\end{array}$ & $\mathrm{~N}=35$ \\
\hline 3 & $\begin{array}{l}\text { Apakah ada Kepercayaan masyarakat terhadap pelaksanaan penyelesaian } \\
\text { sertifikat? } \\
\text { a. Tinggi } \\
\text { b. Sedang } \\
\text { c. Rendah }\end{array}$ & $\begin{array}{c}13 \\
16 \\
6\end{array}$ & $\begin{array}{l}37 \\
46 \\
17\end{array}$ & \\
\hline
\end{tabular}

Selanjutnya nilai korelasi produk momen dapat dihitung sebagai berikut :

$$
\begin{aligned}
& =\frac{1041}{\sqrt{(1384)(1314)}} \\
& =\frac{1041}{1348} \\
& =0,77
\end{aligned}
$$

$$
\begin{gathered}
r x y=\frac{N\left(\sum X Y\right)-\left(\sum X\right)\left(\sum Y\right)}{\sqrt{\left.\left[N\left(\sum X^{2}\right)\left(\sum X\right)^{2}\right] N\left(\sum Y^{2}\right)\left(\sum Y\right)^{2}\right]}} \\
=\frac{35(1641)-(234)(241)}{\sqrt{\left(35\left(1604-(234)^{2}\right)\left(35(1697)-(241)^{2}\right)\right.}} \\
=\frac{57435-56394}{\sqrt{(56140-54756)(59395-58081)}}
\end{gathered}
$$

Copyright (c) 2016, Otoritas : Jurnal Ilmu Pemerintahan, p-ISSN: 2088-3706, e-ISSN: 2502-9320 
Tersedia Online di http://journal.unismuh.ac.id/index.php/otoritas

Otoritas : Jurnal Ilmu Pemerintahan, 6 (1), April 2016, 10

Ternyata nilai korelasi setelah dihitung adalah $r=0,77$. Ini berarti terdapat korelasi yang tinggi antara pelaksanaan prinsip-prinsip good governance dengan kinerja pelayan publik pada BPN Kota Ambon .

Untuk mengetahui signifikansi hubungan antara kedua variabel tersebut diuji dengan menggunakan harga kritik $\mathrm{r}$ pada tingkat signifikansi $95 \%(0,05)$.

Harga kritik $r$ pada $r$ tabel ternyata sebesar 0,325 ini berarti bahwa korelasi tersebut signifikan karena nilai korelasi lebih besar dari nilai $r$ tabel $(0,77>$ $0,325)$.

Dengan demikian korelasi antara kedua variabel dalam penelitian ini yaitu antara pelaksanaan prinsip-prinsip good governance dengan kinerja pelayan publik pada BPN Kota Ambon mempunyai hubungan yang signifikan.

\subsection{Intrepetasi Hasil Penelitian}

Hasil analisis terhadap data penelitian menunjukan bahwa ada hubungan yang signifikan antara pelaksanaan prinsip-prinsip good governance dengan kinerja pelayan publik pada BPN Kota Ambon sebesar $r=$ 0,77 dan signifikan pada tingkat signifikansi $95 \%$ (0.05). Hal ini berarti bahwa pelaksanaan prinsip-prinsip good governance mempunyai pengaruh yang signifikan terhadap kinerja pelayan publik pada BPN Kota Ambon.

Apabila terjadi peningkatan sebesar 0,77 pada variabel pelaksanaan prinsipprinsip good governance maka peningkatan yang sama akan terjadi pada variabel kinerja pelayanan publik. Demikian pula bila terjadi penurunan sebesar 0,77 pada variabel pelaksanaan prinsip-prinsip good governance maka penurunan yang sama akan terjadi pula pada kinerja pelayan publik.

Peningkatan dan penurunan antara kedua variabel tersebut dapat terjadi bila variabel lain yang ikut mempengaruhi kinerja pelayanan publik dianggap konstant atau tidak memiliki pengaruh apa-apa.

Dengan kata lain dapat dikatakan bahwa bilamana pelaksanaan prinsipprinsip goodgovernance semakin tinggi maka kinerja pelayanan publik pada BPN Kota Ambon akan semakin tinggi. Demikian pula sebaliknya bilamana pelaksanaan prinsip-prinsip good governance semakin rendah maka kinerja pelayanan publik pada instansi tersebut akan rendah pula.

\section{Kesimpulan}

Berdasarkan hasil analisis data dapat ditarik kesimpulan, bahwa pelaksanaan prinsip-prinsip good governance mempunyai hubungan yang tinggi yakni sebesar 0,77 dan signifikan pada taraf kepercayaan $95 \%(0,05)$ dengan kinerja pelayanan publik pada BPN Kota Ambon. Ini berarti bahwa hipotesis yang dirumuskan yakni ada hubungan yang signifikan antara pelaksanaan prinsipprinsip good governance dengan kinerja pelayanan publik Kota Ambon teruji kebenarannya.

Terujinya kebenaran hipotesis tersebut berarti antara data yang diperoleh dilapangan penelitian dengan teori berada pada posisi yang sejalan.

\section{Ucapan Terima Kasih}

Kami menghaturkan terima kasih kepada pihak-pihak terkait yang menyukseskan penelitian dan penulisan karya ilmiah ini.

\section{Daftar Pustaka}

Faisal, S. (2010). Format-format penelitian sosial. Jakarta: PT. Raja Grafindo Persada.

Mardiasmo, D. (2009). Akuntansi Sektor Publik. Yogyakarta: ANDI.

Nubatonis, S. E. (2014). Implementasi Prinsip-Prinsip Good Governance Dalam Meningkatkan Kinerja Organisasi Pelayanan Publik. JISIP: Jurnal Ilmu Sosial dan Ilmu Politik, $3,(1), 16-20$.

Santoso, P. (2008). Administrasi Publik 
Tersedia Online di http://journal.unismuh.ac.id/index.php/otoritas

Otoritas : Jurnal Ilmu Pemerintahan, 6 (1), April 2016, 11

Teori dan Aplikasi Good Governance. Bandung: Refika Aditama.

Sedarmayanti, S. (2012). Good Governance. Kepemerintahan Yang Baik \& Good Corporate Governance. Tata kelola Perusahan Yang Baik. Bandung: Mandar Maju.

Siringoringo, W. (2015). Pengaruh Penerapan Good Governance Dan Whistleblowing System Terhadap Kepatuhan Wajib Pajak Orang Pribadi Dengan Resiko Sanksi Pajak Sebagai Variabel Moderating (Studi Empiris Terhadap Wajib Pajak Orang Pribadi Di Kota Bekasi). Jurnal Akuntansi, 19(2), 207-224.

Sulistiyani, A. T. (2011). Memahami Good
Governance dalam Perspektif Sumber Daya Manusia. Yogyakarta: Gava Media.

Tomuka, S. (2013). Penerapan PrinsipPrinsip Good Governance Dalam Pelayanan Publik Di Kecamatan Girian Kota Bitung (Studi Tentang Pelayanan Akte Jual Beli). Jurnal eksekutif, 2, (1), 1-15. 